\title{
Limitaciones de la PAAF en el diagnóstico del pilomatrixoma
}

\author{
FNA limitations in the diagnosis of pilomatrixoma
}

\author{
J.A. García de Marcos' , F. Alamillos Granados², A. Dean Ferrer³, J.J. Ruiz Masera4, A. Vidal Jiménez', \\ J.M. Calderón Bohórquez' ${ }^{1}$ B. Valenzuela Salas ${ }^{1}$
}

Resumen: El pilomatrixoma es un tumor benigno de la piel que procede de la matriz celular del folículo piloso. Se localiza preferentemente en la cara y cuello. Clínicamente se presenta como un nódulo subcutáneo solitario y firme, no doloroso y de lento crecimiento. El tratamiento de elección es la resección quirúrgica.

La PAAF (Punción Aspiración con Aguja Fina), como prueba diagnóstica prequirúrgica, puede hacer confundir el pilomatrixoma con un tumor maligno por la alta concentración de células, junto a la presencia de células aisladas con una tasa aumentada de la relación núcleo/citoplasma.

Presentamos un caso clínico de pilomatrixoma cuyo diagnóstico inicial, tras la PAAF, fue tumor epitelial maligno de bajo grado. Asimismo, realizamos una revisión de la literatura.

Palabras clave: Pilomatrixoma; Pilomatricoma; Epitelioma calcificado de Malherbe; Tricomatrioma; Punción Aspiración con Aguja Fina; Citología.
Abstract: Pilomatrixoma is a benign skin neoplasm that arises from hair follicle matrix cells. The most common anatomical location is the head and neck region. Clinically, it manifests as a firm, solitary, slow-growing, painless nodule of the dermis. Complete surgical excision is the treatment of choice.

With FNAB (Fine Needle Aspiration Biopsy) as a presurgical diagnostic test, the highly cellular smear with isolated cells showing a high nuclear/cytoplasmic ratio can be mistaken for a malignant tumor. We report a case of pilomatrixoma with an initial diagnosis, after the FNAB, of low-grade malignant epithelial tumor. Also, a review of the literature is made.

Key words: Pilomatrixoma; Pilomatricoma; Calcifying epithelioma of Malherbe; Trichomatricoma; Fine Needle Aspiration Biopsy; Cytology.

Recibido: 29.08 .05

Aceptado: 15.11 .05

1 Médico Residente. Servicio de Cirugía Oral y Maxilofacial.

2 Especialista en Cirugía Oral y Maxilofacial. Fellow of the European Board of Oral and Maxillofacial Surgery.

3 Jefe de Sección. Servicio de Cirugía Oral y Maxilofacial. Fellow of the European Board of Oral and Maxillofacial Surgery. Profesor asociado de la facultad de medicina. Universidad de Córdoba.

4 Especialista en Cirugía Oral y Maxilofacial. Servicio de Cirugía Oral y Maxilofacial.

5 Médico Residente. Servicio de Anatomía Patológica.

Hospital Universitario «Reina Sofía». Córdoba, España.

Correspondencia:

J.A. García de Marcos.

C/ Antonio Acuña, 10, 5ํizq..

28009. Madrid, España.

E-mail: pepio2@hotmail.com 


\section{Introducción}

El pilomatrixoma es un tumor benigno de la piel que procede de la matriz celular del folículo piloso.1-3 En 1880, Malherbe y Chenantains describieron la lesión como un tumor benigno subcutáneo que creían que tenía su origen en las glándulas sebáceas. En 1922, Dubreuilh y Cazenave describieron las características histopatológicas de esta neoplasia, incluyendo las islas de células epiteliales y las células fantasmas. En 1961, Forbis y Helwig descubrieron que la célula de origen estaba en la capa externa celular de la raíz del folículo piloso y propusieron el término de pilomatrixoma para describir la lesión (Ref. en Lan y cols. y en Thinakaran y cols.).2,4

Se han utilizado otros términos para definir a esta lesión como: pilomatricoma, epitelioma calcificado de Malherbe o tricomatrioma. ${ }^{1,2}$

Aunque el pilomatrixoma puede aparecer a cualquier edad es más frecuente en la infancia y en la adolescencia y se observa un segundo pico de incidencia en pacientes de 50-65 años. ${ }^{2}$ Es más frecuente la afectación del sexo femenino. Su etiología es desconocida. ${ }^{1}$ El área de cabeza y el cuello es la más comúnmente afectada ( $50 \%$ de las lesiones), seguida de las extremidades superiores, el tronco y las extremidades inferiores. ${ }^{2}$ Clínicamente se presenta como un nódulo subcutáneo solitario, duro y firme, no doloroso y de crecimiento lento durante meses o años. Generalmente es asintomático, pero algunos se asocian con inflamación o ulceración. El tamaño varía de 0,5 a $3 \mathrm{~cm}$ de diámetro, suele ser de forma esférica y con la piel suprayacente del color de la piel normal, o bien rosada o rojo violácea o puede estar ulcerada. ${ }^{1-3}$ El tumor generalmente se desliza libremente sobre su capa subyacente. ${ }^{2}$

El tratamiento de elección es la escisión quirúrgica, siendo rara la recidiva tras la resección completa. La malignización es extremadamente rara. ${ }^{1,2,5}$

La PAAF (Punción Aspiración con Aguja Fina) se está utilizando cada vez de manera más frecuente para el diagnóstico de masas patológicas de cabeza y cuello, y en manos expertas tiene una alta sensibilidad y especificidad. 3,4,6 En el pilomatrixoma, la alta concentración de células, junto a células aisladas con una tasa aumentada de la relación núcleo/citoplasma, puede hacer confundir en la punción con un tumor maligno. 4,7 Presentamos un caso clínico de pilomatrixoma cuyo diagnóstico, inicial, tras la PAAF, fue tumor epitelial maligno de bajo grado.

\section{Caso clínico}

Paciente mujer, de 17 años de edad, que acude a nuestro Servicio, para estudio y tratamiento de nódulo en piel de zona parotídea derecha, de 6 meses de evolución, doloroso a la palpación y de crecimiento progresivo. No tenía antecedentes médicos ni quirúrgicos de interés.

A la exploración física se apreciaba un nódulo preauricular, de $1 \mathrm{~cm}$ de diámetro, situado a $1 \mathrm{~cm}$ del pliegue preauricular, de consistencia dura, adherido a la piel y no adherido a planos profundos (Fig. 1). En el cuello se palpaban adenopatías rodaderas submandibulares bilaterales inespecíficas.

\section{Introduction}

Pilomatrixoma is a benign neoplasm of the skin that arises from hair follicle matrix cells. ${ }^{1-3}$ In 1880 Malherbe and Chenantains described the lesion as a benign subcutaneous neoplasm that they believed originated in the sebaceous glands. In 1922 Dubreuilh and Cazenave described the histopathologic characteristics of this neoplasm that included islands of epithelial cells and ghost cells. In 1961, Forbis and Helwig discovered that the original cell was in the external cellular layer of the hair follicle and they proposed the term pilomatrixoma to describe the lesion (Ref. Lan and cols. and Thinakaran and cols.).2,4

Other terms have been used for defining this lesion such as pilomatricoma, calcifying epithelioma of Malherbe, or tricomatrioma. ${ }^{1,2}$

Although pilomatrixoma may appear at any age it is more common during infancy and adolescence and a second peak in incidence is observed in patients between the ages of 50-65. It more commonly affects the female sex. It is of unknown etiology. 'The area of the head and neck is most commonly affected ( $50 \%$ of lesions), followed by the upper extremities, trunk and lower extremities. ${ }^{2}$ Clinically it presents as a solitary subcutaneous nodule that is hard, firm and painless, and which grows slowly over months or years. It is generally asymptomatic, but some are associated with inflammation or ulceration. Its size varies and it can measure 0.5 to $3 \mathrm{~cm}$ in diameter. It tends to have a sphere shape and the overlying skin can be of the normal skin color, or pinkish, purplish red or it can be ulcerated. ${ }^{1-3}$ The tumor generally moves freely over the underlying tissue. ${ }^{2}$

The treatment of choice is surgical excision with relapse being uncommon following complete resection. Malignant transformation is extremely rate. 1,2,5

FNA (Fine Needle Aspiration) is being used increasingly for the diagnosis of pathological masses of the head and neck, and in expert hands it has high sensibility and specificity.3,4,6 The highly cellular smear, with isolated cells showing a high nuclear/cytoplasm ratio can lead pilomatrixoma to be mistaken for a malignant tumor. ${ }^{4,7}$ We present the clinical case of pilomatrixoma which was initially diagnosed as a low-grade malignant epithelial tumor.

\section{Case Report}

Female patient, 17 years old, attended our department for the study and treatment of a nodule in the skin by the right parotid area that had been evolving for six months. It was painful to palpation and it was growing steadily. She had no medical or surgical history of interest.

On physical exploration a preauricular nodule could be appreciated with a $1 \mathrm{~cm}$ diameter that was situated $1 \mathrm{~cm}$ away from the preauricular fold. It was hard in consistency 
Se realizaron una ecografía, una Resonancia Magnética (RM) y una PAAF. En la ecografía se apreciaba un formación ovalada de $1 \times 0,6 \mathrm{~cm}$ de tamaño, de ecogenicidad heterogénea y con vascularización que hacía sospechar de un proceso angiomatoso. En la RM se objetivó una lesión ovalada, hipointensa tanto en T1 como en T2, y bien delimitada, situada en el tejido celular subcutáneo de la región preauricular derecha y adyacente a la piel. La lesión era independiente de la glándula parótida (Fig. 2). El diagnóstico de sospecha tras la RM fue de adenopatía o angioma. En la PAAF se aprecian una alta celularidad, alta tasa núcleo/citoplasma, nucleolos prominentes y apariencia primitiva de las células basaliodes (Fig. 3A). Se apreciaba también alguna célula gigante multinucleada (Fig. 4A). El informe de la PAAF fue de tumor epitelial de bajo grado de malignidad no específico.

Con los datos de la clínica, la exploración, pruebas radiológicas y de la PAAF, el diagnóstico clínico de sospecha fue de tumor anexial maligno.

A las dos semanas de la primera consulta y bajo anestesia local, se realizó una resección de la lesión, con la piel suprayacente y el tejido adiposo que la rodeaba. La lesión era amarillenta y de consistencia dura (Fig. 5). Al estudio histológico se observan células organizadas en círculos, con células con núcleo, basalioides en la periferia y células fantasma sin núcleo en el centro (Fig. 3B).

Aparecen áreas de reacción a cuerpo extraño, con una reacción granulomatosa a células fantasmas, en las zonas donde hay abundante contenido de desecho queratinizado (Fig. 4B). El resultado anatomopatológico fue de pilomatrixoma. Tras nueve meses de la cirugía no hay signos de recidiva o complicación.

\section{Discusión}

Aunque la etiología del pilomatrixoma es desconocida se han determinado como posibles factores implicados en su aparición el gen de la distrofia miotónica y el polyoma virus. Muchas investigaciones han demostrado que el pilomatrixoma está frecuentemente asociado con las mutaciones en el gen CTNNB1, que implican directamente a una alteración de la regulación de la $\beta$-catenina/LEF. Además, existe una asociación del pilomatrixoma con una serie de enfermedades genéticas como la distrofia miotónica, el xeroderma pigmentoso, el síndrome de Rubinstein-Taybi, el sín-

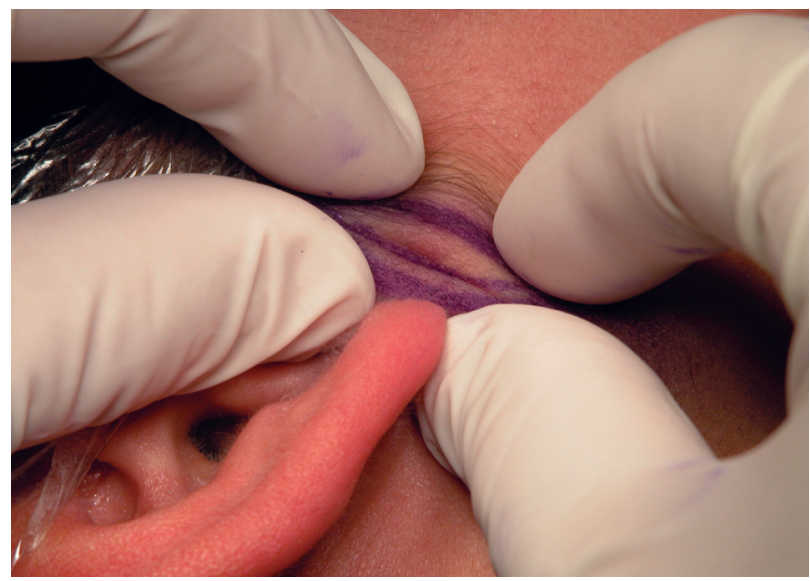

Figura 1. Aspecto externo de la lesión.

Figure 1. External appearance of the lesion.

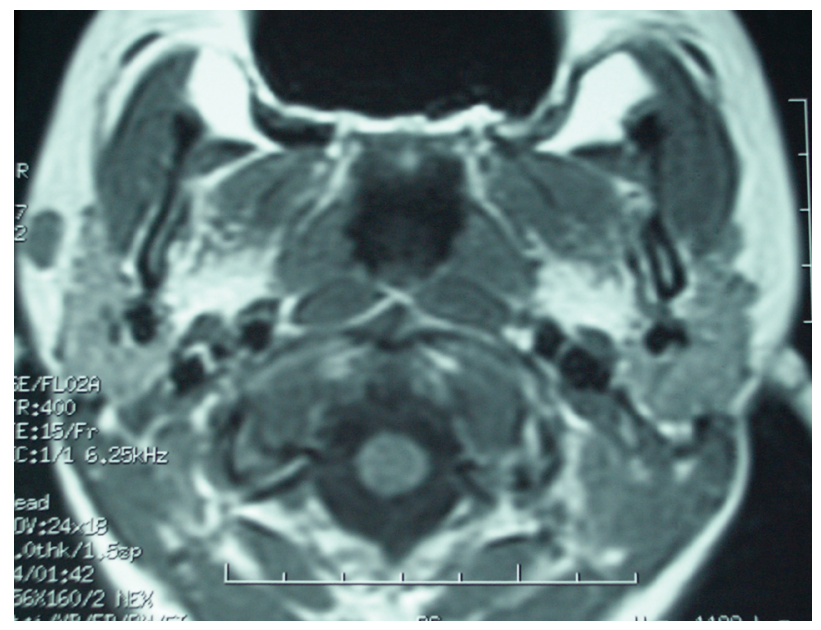

Figura 2. Imagen de RM de la lesión. Figure 2. MR image of the lesion. and it was adhered to the skin and not to the underlying tissue (Fig. 1). Unspecific, round and swollen lymph nodes could be felt with a submandibular, bilateral location.

Ultrasound and Magnetic Resonance (MR) was carried out together with FNA. The Ultrasound examination revealed an oval formation measuring $1 \times 0.6 \mathrm{~cm}$ in size that had heterogeneous echogenicity with vascularization, which led to the suspicion of an angiomatous condition. The MR showed an oval lesion that was hypointense on T1-weighted images as well as on T2weighted images. It was well-defined, and situated in subcutaneous cellular tissue in the right preauricular region and adjacent to the skin. The lesion was independent of the parotid gland (Fig. 2). The suspected diagnosis after MR was of adenopathy or angioma. FNA showed high cellularity, a high nuclear/cytoplasmic ratio, prominent nucleoli, and basaloid cells with a primitive appearance (Fig. 3A). A few multinucleated giant cells could also be appreciated (Fig. 4A). FNA reported a non-specific epithelial tumor of low-grade malignancy.

In view of the information gained from her medical examinations, radiological tests and FNA, the clinical diagnosis was of malignant adnexal tumor.

Two weeks after the first consultation and under local anesthesia, the lesion was resected together with the overlying skin and the adipose tissue that was surrounding it. The lesion was yellowish and hard in consistency (Fig. 5). The histological study revealed cells organized in circles, cells with nuclei, peripheral basaloid cells and ghost cells with no nuclei in the center (Fig. 3B). There were areas of foreign body reaction, with granulomatous reaction to ghost cells in areas where there was large amounts of keratinized debris (Fig. 4B). The anatomopathologic result was of pilomatrixoma. Nine months after the surgery there were no signs of relapse or complications. 
drome de Turner, el síndrome de Goldenhar y la sarcoidosis. ${ }^{1}$ Se han observado cambios similares al pilomatrixoma en los quistes cutáneos de pacientes con síndrome de Gardner o síndrome névico basocelular. ${ }^{1}$

En cabeza y cuello está situado generalmente en la mejilla, en la región preauricular, la frente, el cuello, región periorbitaria y el cuero cabelludo. ${ }^{3} \mathrm{El}$ tamaño de las lesiones varía entre 0,5 y $3 \mathrm{~cm}$ en la mayoría de los casos, 2,3 aunque han sido descritas lesiones gigantes de hasta $15 \mathrm{~cm}$. El caso que presentamos estaba situado en la región preauricular y su diámetro mayor era de $1 \mathrm{~cm}$.

El diagnóstico se puede sospechar por su localización y la consistencia firme del tumor, que cuando se presiona permite apreciar su forma de «piedra facetada» y se pone de manifiesto el signo de la «tienda de campaña» debido a la calcificación de la lesión. El diagnóstico diferencial en cabeza y cuello debe realizarse con los quistes dermoides y epidermoides, lipomas calcificados, quistes branquiales, tumores de células gigantes, nódulos linfáticos calcificados, condromas, fibroxantoma degenerado, reacción a cuerpo extraño, hematomas calcificados, osteomas cutáneos, hemangiomas y tumores de la glándula parótida. ${ }^{1-3}$

Las pruebas radiológicas tienen poco valor para diagnosticar el pilomatrixoma. La Tomografía Computarizada muestra una lesión subcutánea claramente demarcada y con calcificación. La Resonancia Magnética muestra imágenes de alta intensidad en T2, que se correlacionan con las bandas formadas por las células basalioides, que se evidencian en el estudio histopatológico. La ecografía es una prueba rápida e inocua y puede ayudar al diagnóstico determinando la profundidad de las masas. ${ }^{2}$ En la ecografía se aprecia una periferia hipoecoica que corresponde con el tejido conectivo de la cápsula y un centro hiperecoico que corresponde con las células epiteliales del centro. En la ecografía también puede apreciarse la calcificación. Además, en las lesiones de la región parotídea ayuda a delimitar su relación con la glándula parótida.

La PAAF se utiliza como método diagnóstico preoperatorio.2,4 Actualmente está considerada como la prueba con mejor relación coste beneficio en el diagnóstico de tumores de cabeza y cuello. ${ }^{6}$ El principal error diagnóstico en este tipo de tumores cuando se uti-
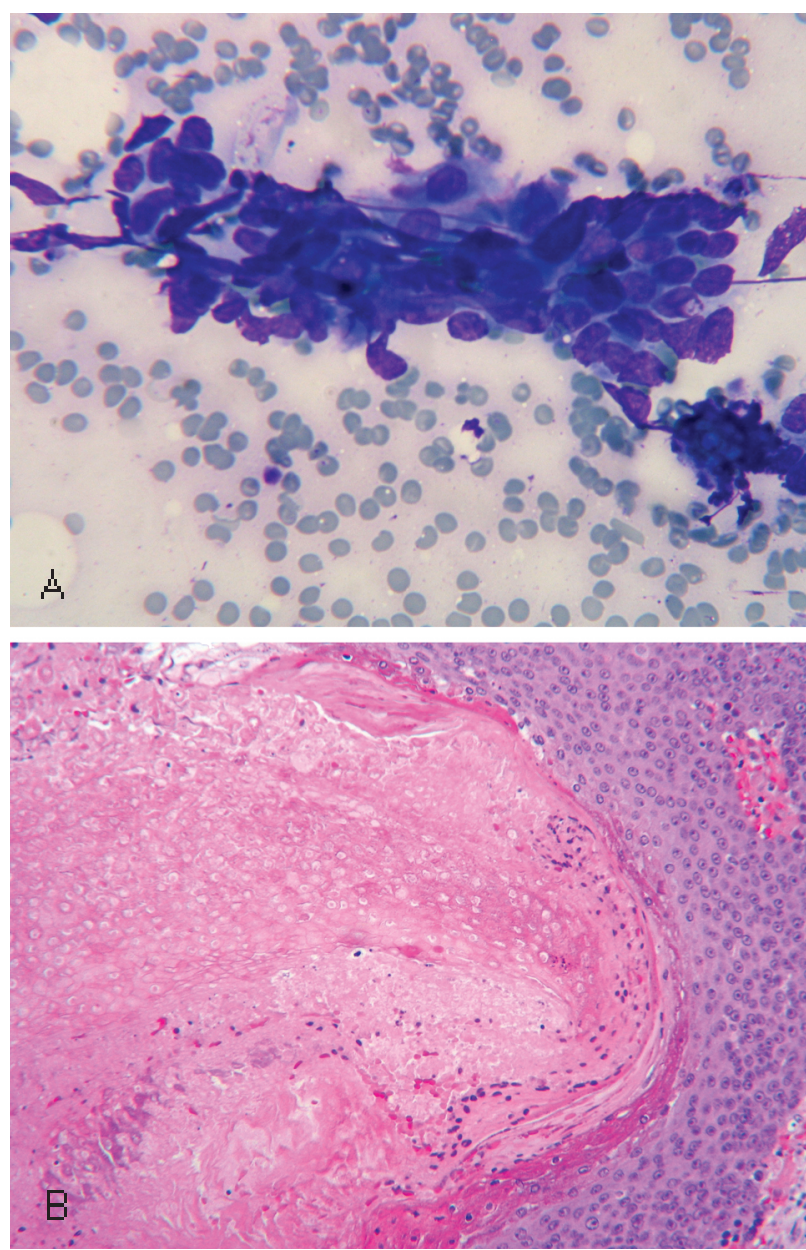

Figura 3. Pilomatrixoma. A) citología por punción teñida con panóptico, que muestra un grupo de células de escaso citoplasma y con artefacto de estiramiento, lo que sugiere un tumor de células pequeñas, y que tras la evaluación de la histología de la lesión podría corresponder a las células basalioides. B) corte histológico teñido con hematoxilina-eosina, que muestra las células basalioides con citoplasma escaso (A) y las células fantasma eosinófilas (B).

Figure 3. Pilomatrixoma. A) Puncture cytology with panoptic staining that shows a group of cells with scant cytoplasm and with an extension atifact that suggests a small-cell tumor and that, following evaluation of the histology of the lesion, could correspond to basaloid cells. B) histological slice with hematoxylin-eosin stain showing basaloid cells with scant cytoplasm $(A)$ and ghost cells with eosin stain (B).

\section{Discussion}

Although the etiology of pilomatrixoma is unknown, the myotonic dystrophy gene and the polyoma virus have been identified as possible factors connected with its appearance. Many investigations have shown that pilomatrixoma is frequently associated with the mutations of the CTNNB1 gene, which directly imply a change in the regulation of $\beta$-catenin/LEF. In addition pilomatrixoma has been linked with a series of genetic diseases such as myotonic dystrophy, xeroderma pigmentosum, Rubinstein-Taybi syndrome, Turner syndrome, Goldenhar syndrome and sarcoidosis.' Similar changes to those identified in pilomatrixoma have been observed in patients with Gardner's syndrome or basal cell nevus syndrome. ${ }^{?}$

In the head and neck it is generally to be found in the cheek, the preauricular area, forehead, neck, periorbital region and scalp. ${ }^{3}$ The size of the lesions varies between 0.5 and $3 \mathrm{~cm}$ in most cases, 2,3 although giant lesions of up to $15 \mathrm{~cm}$ have been described. The case we present was situated in the preauricular region and the widest point was $1 \mathrm{~cm}$.

The diagnosis can be suspected taking into account the location of the tumor and its firm consistency, which when pressed shows its «faceted stone» texture and «tent sign» due to the calcification of the lesion. The differential diagnosis in the head and neck should be made with the dermoid and epidermoid cysts, calcifying lipoma, branchial cyst, giant cell tumor, lymphatic calcifying nodules, chondroma, degenerative fibroxanthoma, foreign body reaction, calcifying hematoma, cutaneous osteo$\mathrm{ma}$, hemangioma and tumors of the parotid gland. ${ }^{1-3}$

The radiological tests are of little value when diagnosing pilomatrixoma. Computed Tomography shows a subcutaneous lesion that is clearly demarcated and with calci- 
liza la PAAF, como prueba diagnóstica, es un falso positivo de malignidad. $2,3,4,8$ Citológicamente el diagnostico diferencial se debe realizar con el carcinoma epidermoide, el carcinoma basocelular y la metástasis del carcinoma de células pequeñas. ${ }^{4}$ Los resultados pueden ser engañosos cuando no se encuentran células fantasmas en el aspirado, hecho que se produce habitualmente. La alta celularidad, la alta tasa núcleo/citoplasma, los nucléolos prominentes y la apariencia primitiva de las células basaliodes pueden llevar a realizar un diagnóstico erróneo de malignidad, ${ }^{7}$ como sucedió en nuestro caso. Sin embargo, las células basalioides del pilomatrixoma son uniformes y tienen más cromatina abierta, con pequeños nucléolos, mientras que las células carcinomatosas son más oscuras y pleomorfas y tienen una fina y densa cromatina con macronucléolos. Otra característica de las células carcinomatosas es la presencia conjunta de una prominente población de células linfoides, con un buen número de células plasmáticas y eosinófilos, ocasionalmente células aberrantes y lobuladas, y macrófagos con cuerpo teñible. ${ }^{7}$ Además de estas diferencias, la historia clínica, la presencia de las células fantasma características, la ausencia de atipia y de mitosis, los depósitos de calcio y la presencia de células gigantes multinucleadas deben ayudar a hacer el diagnóstico correcto. ${ }^{4,7}$ En su ausencia, la obtención de una segunda opinión, la repetición de la aspiración y el uso de extensiones secadas al aire debería ayudar a realizar
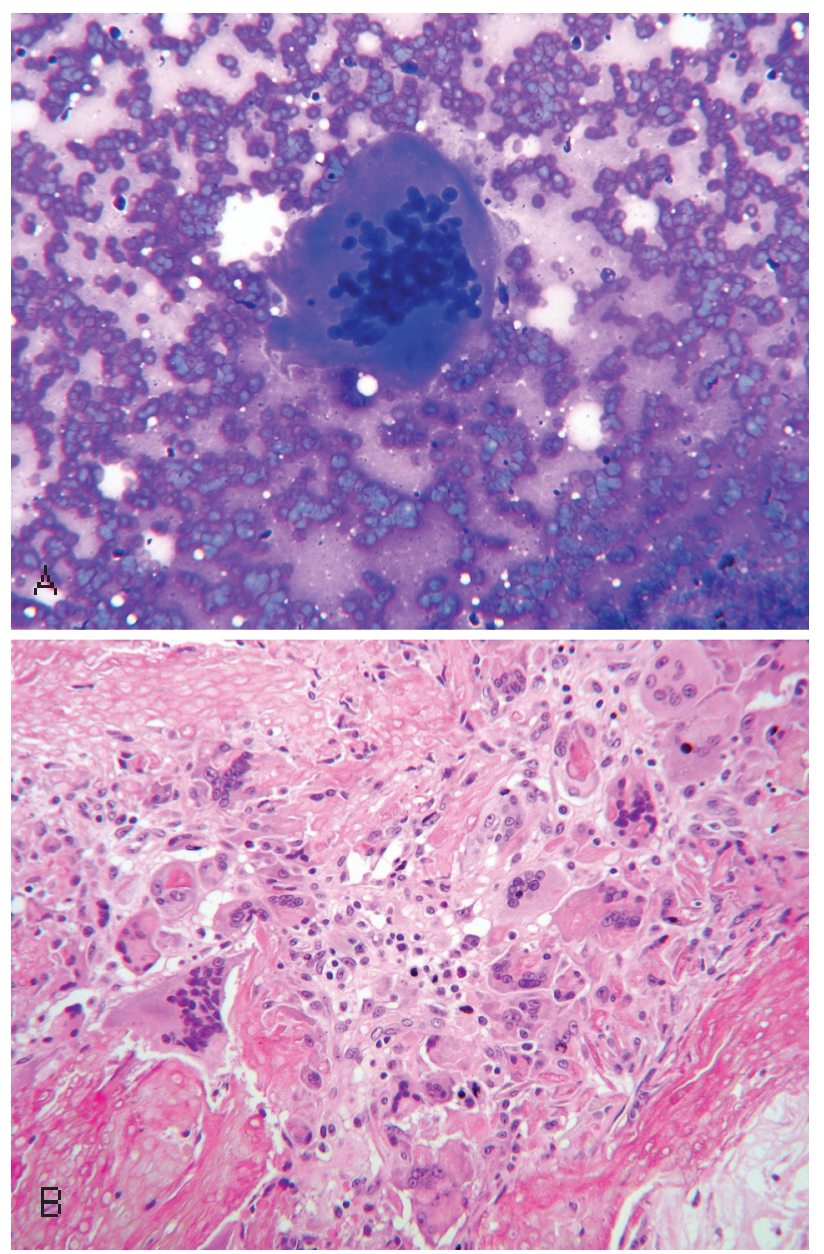

Figura 4. Células gigantes multinucleadas como reacción a la queratina de las células fantasma, cuya evaluación apropiada en la citología por punción podría haber supuesto la única pista disponible hacia el diagnóstico correcto. A) citología por punción teñida con panóptico. B) corte histológico de la pieza teñido con Hematoxilina-Eosina.

Figure 4. Multinucleated giant cells in response to the keratin of the ghost cells. Had this been evaluated properly in the puncture cytology, it would have provided the only lead to a correct diagnosis. A) puncture cytology with panoptic stain. B) histological slice of the specimen with hematoxylin-eosin stain. fications. Magnetic Resonance shows images with high intensity on T2-weighted images, which correlate with the bands formed by basaloid cells appearing in the histopathological study. The sound scan is a fast, innocuous test that can help with the diagnosis by determining the depth of the mass. ${ }^{2}$ Ultrasound shows a hyper-echoic edge corresponding to the connective tissue of the capsule, and a hyper-echoic center corresponding to the epithelial cells of the center. The calcifications can also be appreciated with ultrasound which also helps to clarify the relationship of the lesions in the parotid region with the parotid gland.

FNA is used as a diagnostic preoperative method. ${ }^{2,4}$ It is currently considered a test with a better cost-benefit ratio for diagnosing tumors of the head and neck. ${ }^{6}$ The principal diagnostic error for this type of tumor when using FNA as a diagnostic study, is a false positive result for malignancy. ${ }^{2,3,4,8}$ The cytological differential diagnosis should include epidermoid carcinoma, basil cell carcinoma and metastases of smallcell carcinoma. ${ }^{4}$ The results can deceive when ghost cells el diagnóstico en los casos difíciles. ${ }^{5,7}$

No existe una correlación entre el tipo histológico y el tiempo de evolución clínica o el tamaño del tumor. ${ }^{1}$ Dado que no se han descrito remisiones espontáneas en este tipo de lesiones, el tratamiento es la escisión quirúrgica. Ocasionalmente la piel suprayacente se ha de resecar debido a la adherencia del tumor a la dermis. ${ }^{1-3}$ La recurrencia del pilomatrixoma tras la cirugía es rara y ocurre con una incidencia del 0 al 3\%.2,6 La aparición de una segunda lesión en otra parte del cuerpo es raro y el riesgo disminuye progresivamente con la edad.

Además del pilomatrixoma, existen otras lesiones benignas, en cabeza y cuello, en las que se puede realizar un diagnóstico erróneo de malignidad tras la realización de la PAAF. Estas son las siguientes: el quiste branquial, que se puede confundir con el carcinoma epidermoide bien diferenciado, y el ganglio linfático con linfade- are not found in the aspirate, which is a frequent occurrence. High cellularity, high nuclear/cytoplasmic ratio, prominent nucleoli and the primitive appearance of basaloid cells can lead to an erroneous diagnosis of malignancy, ${ }^{7}$ as occurred in our case. However, the basal cells of pilomatrixoma are uniform and there is more of an open chromatin structure with small nucleoli. Carcinomatous cells are darker and more pleomorphic with chromatin that is fine and dense, and macronucleoli. Another characteristic of carcinomatous cells is the additional presence of a prominent population of lymphoid cells, a considerable number of plasmatic and eosinophilic cells with occasional aberrant lobulated cells, and tingible body macrophages. ${ }^{7}$ In addition to these differences, the medical history, presence of characteristic ghost 
nitis folicular reactiva, que se puede confundir con un linfoma de tipo centroblástico/centrocítico. ${ }^{8}$

\section{Conclusiones}

Ante una lesión clínicamente sugerente de tumor anexial, con una PAAF que indica un tumor epitelial de bajo grado, debe hacerse hincapié al anatomopatólogo de la posibilidad de un pilomatrixoma para que revise el estudio citológico.

\section{Agradecimientos}

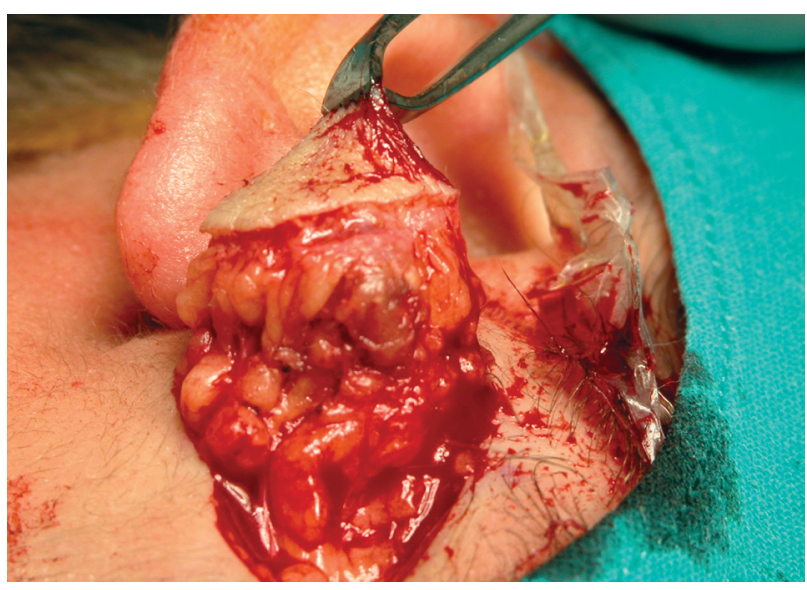

Figura 5. Imagen de la escisión quirúrgica de la lesión. Figure 5. Image corresponding to the surgical excision of the lesion. cells, absence of atypia and of mitoses, presence of calcium deposits and multinuclear giant cells should help in making a correct diagnosis. ${ }^{4,7}$ If absent, obtaining a second opinion and repeating the aspiration, together with the use of airdried smears, will help in the diagnosis in those cases that are difficult. 5,7

There is no correlation between histological type, the time over which the nodule has been evolving clinically, or the size of the tumor. ${ }^{\text {In }}$ view of spontaneous remissions not being described

Al Dr. Pérez-Seoane Orduña (Médico Adjunto. Servicio de Anatomía Patológica. Hospital Universitario Reina Sofía. Córdoba, España).

\section{Bibliografía}

1. Pirouzmanesh A, Reinisch JF, González Gómez I, Smith EM, Meara JG. Pilomatrixoma: a review of 346 cases. Plast Reconstr Surg 2003;112: 1784-9.

2. Lan MY, Lan MC, Ho CY, Li WY, Lin CZ. Pilomatricoma of the head and neck: a retrospective review of 179 cases. Arch Otolaryngol Head Neck Surg 2003;129:137-30.

3. Green RM, McGuff HS, Miller FR. Pilomatrixoma of the face: a benign skin appendage mimicking squamous cell carcinoma. Otolaryngol Head Neck Surg 2004;130: 483-5.

4. Thinakaran V, Singh SK, Simples $P$, Nadimpalli V. Fine needle aspiration diagnosis of pilomatrixoma. A case report. Acta Cytol 1998;42:769-71.

5. Naval L, García Sánchez A, Duran R, Rodríguez F, Alamillos F, Dean A, Fernández J. Pilomatrix carcinoma. A new case. Rev Stomatol Chir Maxillofac 1991;92:4850.

6. Ferlito A, Boccato P, Shaha AR, Carbone A, Noyek AM, Doglioni C, Bradley PJ, Rinaldo A. The art of diagnosis in head and neck tumors. Acta Otolaryngol 2001;121:324-328.

7. el Hag IA, Kollur SM. Fine needle aspiration cytology of pilomatrixoma of the neck region: differentiation from metastatic undiffentiated nasopharyngeal carcinoma. Acta Cytol 2003;47:526-8.

8. Skoog L, Tani E. Lymph Nodes. En: Gray W, Mckee GT. Diagnostic Cytopathology. Elsevier Science Limited. Londres. 2003;pp.501-36. cal excision. Occasionally the overlying skin has to be resected due to the tumor adhering to the dermis..$^{1-3}$ It is very rare for pilomatrixoma to recur after surgery, and the incidence of this is $0-3 \% .^{2,6}$ The appearance of a second lesion in another area of the body is rare, and the risk diminishes progressively with age. ${ }^{8}$

In addition to pilomatrixoma, there are other benign lesions of the head and neck that can be diagnosed erroneously as malignant lesions after carrying out FNA. They are the following: branchial cyst that can be confused with the well-differentiated epidermoid carcinoma, and the lymphatic node, with reactive lymphadenopaty, that can be confused with a centroblastic/centrocytic type of lymphoma.

\section{Conclusion}

When faced with a lesion that is clinically suggestive of an adnexal tumor and with FNA that indicates a low-grade epithelial tumor, it should be stressed to the anatomopathologist that there is a possibility of pilomatrixoma so that the cytological analysis is reviewed.

\section{Acknowledgments}

We would like to thank Dr. Pérez-Seoane Orduña (Assistant pathologist. Department of Pathological Anatomy. Hospital Universitario Reina Sofía. Córdoba, Spain). with this type of lesion, treatment should consist in surgi- 